鉱物学雅誌 第 8 巻 特別号・第 2 号 $1 \sim 61 \quad$ 1968年 3 月

鉱 物 学 杂隹 誌

第 8 巻 特别号第 2 号 1968 年 3 月

話題提供および討論

第 1 セッション：

鉱物の化学組成および物理性質と生成環境

マンカン輝石類について

Some Manganese Pyroxenoids

桃 井斉 ( Hitoshi Momoi )

マンガン輝石類は近年 pyroxenoid の名前で総括され興味ある結晶学的成果がえられ， 轨酸塩の中でも特異な位置を占めている。しかしその相関係てつては不明な点が少くな い。とくに rhodonite 類は日本のマンガン鉱床の主要な鉱石の1つであり，てれらの相 関係を明らかにするととは，鉱床の成因を考える上に重要な問題を提供するものと思われ る。今回行なった合成実験は $\mathrm{MnSiO}_{\mathbf{2}}$ - $\mathrm{CaSiO}_{\mathbf{2}}$ 系の中でMn端成分に近い部分で,出 現する輝石類は rhodonite ・ pyroxmangite・bustamite である。このほか inesite • johannsenite も期待できるが今回の実験条件ではえられなかった。 $\mathrm{MnSiO}_{\mathbf{3}}$-CaSiC 系の研究はてれまでにいくつか報告されているが, 1958 年に LIEBAU et al.は $\mathrm{MnSiO}_{\mathbf{3}}$ には $\boldsymbol{\alpha}$ 形 (pseudowoliastonite 構造)・业形 ( wollastonite構造) ・r形（rhodonite構造）の3多形があるととを述べた。また 常圧下に扔ける液相線付近の状態図はMUAN とGLASSER（1962 )によって完成した。

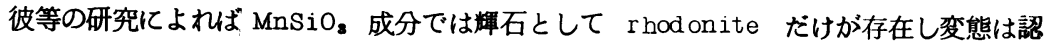
められなかった。そして Ca を約 5 モル\%まで固溶するてとを明らかにした。一方高龶下

* 九大理学部 
での取报いは吉永と垍により熱力学的計算から行なわれた。すなわち菱マンガン鉱と石 英から rhodonite に転移する平衡曲線を $500^{\circ} \mathrm{C}$, 数 $\mathrm{Kb}$ の範囲でPーT四上に示した。

天然産の rhodonite と Pyroxmangite ではいずれも $\mathrm{MnSiO}_{\mathbf{s}}$ 端成分に近い化学 組成を有するものがあるととはすでに報告したが( Momoi，1964)）, 今回はとくにと の両者の関係を明らかにするため, $\mathrm{MnSiO}_{3}$ - ( Mno.7 Ca0.3 $) \mathrm{SiO}_{\mathbf{3}}$ の範囲で熱水合成を 試みた。装置は test - t ube 型のボンべを使用し, $400^{\circ} \sim 700^{\circ} \mathrm{C}, 1 \sim 4 \mathrm{~Kb}, 4 \sim$ 7 日間で実験を行なった。出発物質には特級試薬の炭酸塩とシリカゲルの機械的混合物 を使用した。合成物の同定には主としてX線粉末回折を用いたが，同時に顕微鏡による 観察を行なった。後者はとくに bustami te の同定に有効であるが, rhodonite と pyr oxmangite の区別は生成物が $20 \mu$ 以下のために困難であった。

\section{天然産 rhodonite}

天然に産する rhodonite の化学組成についてはすでに報告したが（Momoi， 1964 ), 産状と固溶する Ca の量からつぎの 4 ふ分類するととが出来る。(1)秩父古 生層中にあり接触変成作用によって明膫なホルンフエルス構造をもつもの（例 田口・ 久杉鉱山等）。C CaSiOs は 4 11 モル\%で一番少い。(2) 秩父古生層中に見られる (1) 以外の rhodonite質鉱石であり, 粗晶でしばしば数 $\mathrm{cm}$ 以上の辟開面をもつとと がある (例 加蘇・大和鉱山等)。CaSiOsは 8〜 13\%。（3）マンガン鉱石を切る後 成の方解石脈中に見られる rhodoniteで, しばしば自形を呈する（例 穴内・秋元鉱 山等)。CaSiO: は $12 \sim 17 \%$ (4)石灭岩に直接して産するスカルンの産状を示す もの(例 秩父鉱山等)。CaSiO\&は15〜20\%。

てれらの産状から，（1）（3）は次第に生成温度が低くなり，(4)ではふたたび高温 になると考えられる。

\section{天然産 pyroxmangite}

天然の pyroxmangiteでは Mn は C a よりはむしろ Fe と広触囲に固溶するので， ( $\mathrm{Mn}, \mathrm{Ca}) \mathrm{SiC}_{\mathbf{3}}$ よりは（ $\left.\mathrm{Mn}, \mathrm{Fe}\right) \mathrm{SiO}_{\mathbf{3}}$ の化学式で示した方がよい鉱物である。

LIEBAU 等によれば結晶棈造の立場から $\mathrm{Mn}=6: 1$ の割合まで Ca を固溶しうる てとが明らかにされている。 pyroxmangiteの産状についてはつぎの 2 通りがある。 (1)ペグマタイトから産するものが古くから知られている。Fe を多量に含み黒色を呈 する場合が多い。マンガン鉱床に産するものが赤〜紅色を示すのと対照的である。（2） マンカン鉱床でもぺグマタイトの影警をうけ野田玉川釷山等に多産するのは興味深い。 マンガン鉱石を切るアラバンド鉱・菱マンガン鉱脈中や(例 高森・岩戸鉱山等 ), ベ メント石またはペンヴィス石脈中に産するものはしばしば自形美晶である(例 田口・ 野田玉川鉱山等)。ハウスマ鉱を主とするチョコレート鉱と周囲の珪岩質の部分の境 
界部に反応縁のように産する（例 荒倉鉱山等）。以上のようにマンガン鉱床に産する ものは共通して Ca, Fe の含有量が少なく，ペグマタイトの影響をうけたものを除けば低 温の産状を示すものが多い。

Rhodonite と Pyroxmangite の共生する例は少く, SUNDIUSによる eulysite 中のものがある。日本では別子・新宮のようなキースラーガーの上盤に産するもの（桃井， 1963 )，ママンガン鉱床に産するもの(須崎，1963）が報告されている。

\section{実驗結果}

結果を第 1 困に示す。 $400^{\circ} \mathrm{C}$ に扑る実験も行なったが反忘が完全でないのと,炭酸 塩から珪酸塩への転移は本稿の主題からはなれるので省略した。との結果をすぐに天然の 生成条件と結び付けるのは危険であるが, 今後の研究の問題点を明らかにする意味で若干 の考察を加えてみたい。
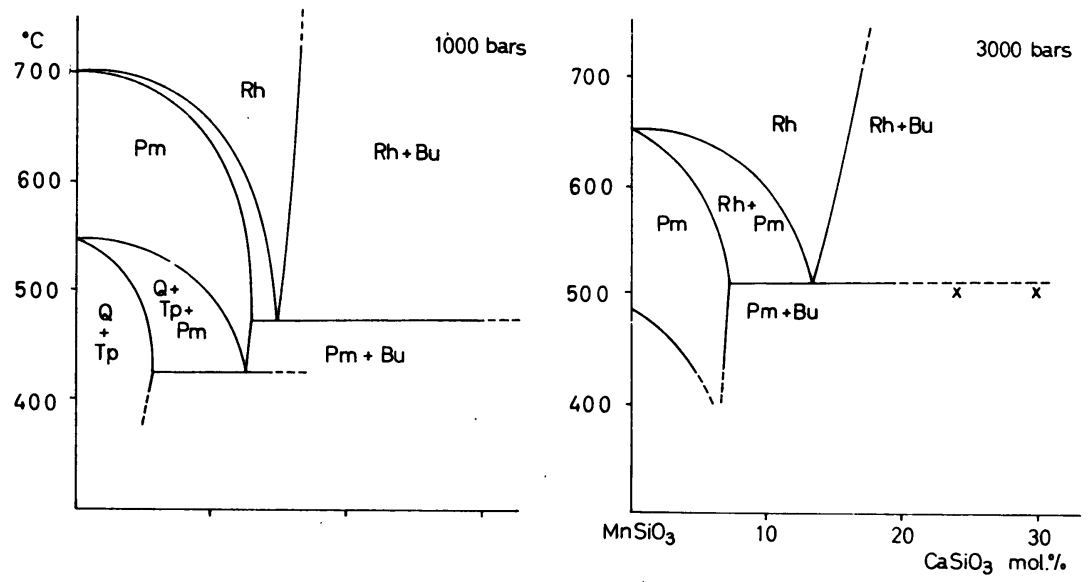

第1四 熱水合成とよる $\mathrm{MnSiO}_{\mathbf{3}}$ - (Mn, Ca) $\mathrm{SiO}_{\mathbf{3}}$ 系の状態図

$\mathrm{Rh}$ : rhodonite, $\mathrm{Pm}$ : pyroxmangite, Bu.: bustamite, Tp : tephroite, $\mathrm{Q}:$ quartz, X: bustamite だけの鉱物相を示す。 
Rhodonite だけの領域は，温度ないし王力が上昇すると拡ってくる。すなわち $1 \mathrm{~Kb}$ では $700^{\circ} \mathrm{C}$ 以上でないと $\mathrm{MnSiO}_{3}$ は rhodonite 構造をとらないが， $3 \mathrm{~Kb}$ では $650^{\circ} \mathrm{C}$ 以 上で存在する。Ca. が増加すると領域は次第に低温側て㹡がり $15 \sim 16$ モル\% ( $\mathrm{CaSiO}_{2}$ ) で最低の $500^{\circ} \mathrm{C}$ 位に達する。しかしさらに Ca. が增加すると rhodonite 単相域は急速に 高温側に後退し，18〜20モル\%以上では bustamite との 2 相になる。これらの結果 は天然産 rhodonite が Ca 量の增加につれて低温で生成する産状を示すてとと, 10 15 モル\%位のものが多く産するてとを説明してるように思われる。したがって，結晶構 造中で可能な最大の 20 モル\% を含むものはかなりの高温下での生成が考えられ，秩父鉱 山のような石闩岩接触部のものがてれと相当すると思われる。

Pyroxmangite の領域は rhodoniteよりはつねに低温側と存在する。すなわち pyroxmangiteは $\mathrm{MnSiO}_{3}$ の低温変態といえる。二の領域は圧力增加とともに低温側 に移動し，範囲も狭くなる。前述のように天然では Fe の少ないものが比较的低温で産す るが, 実験結果はての事実と調和しているようである。また低圧下のものが Ca を多く固 溶できるということは市俣・山中鉱山産のものが Ca を多く含むことと矛盾しない。

Rhodonite と pyroxmangite が共存する領域は低圧下では狭いが, 圧力の增加とと もに拡大するようである。このことは広域変成岩中で両者がしばしば共存する例（別子鉱 山等）を説明できるかも知れないが，今後さらに高圧下での実験を行なう必要があ万う。

石英とテフロ石の共存領域は，石英十テフロ石十 pyroxmangite の領域をへて pyroxmangiteだけの領域より低温側と存在する。てれ海然見られない共生である。 1 つの可能な説明は, 天然のての温度領域では酸素分圧が影響して braunite ができる ためかも知れない。

合成 bustamite 9 問題

$600^{\circ} \mathrm{C}$ 以上・CaSi Os 15 モル\%以上では bustamite が rhodonite と散存して現 われる。また $500^{\circ} \mathrm{C} \cdot 3 \mathrm{~Kb}$ 以上・CaSiOs 30 モル\%以上の㬰験では生成物に bustamite だけが存在する場合（第1図中の×印）のあることが分った。ⓐ が少ない時は pyroxmangite と bustamite が現われるが，ての境界は压力增加とともに低 Ca 側 に移動するらしいすすわち bustamite は熱水合成実験では低温・高压下でも存在す るのであって（低温型？），従来 bustamiteが高温下で安定であると考えられていたの と（高温型？）異なっているように思われる。高温型は Glasser 等により珠灰石と広範 囲の固溶体を形成するてと，johannsenite，inesite, rhodonite 等の常圧下で の加熱とよって生成するてとが知られている。線粉末医形によれば両型の bustamite で差巽があるように思われる。とくに $2 \theta$ （FeK $\boldsymbol{\alpha} ） 25 \sim 30^{\circ} \mathrm{C}$ の範囲では, 高温型で顕 著な反射が見られるが，低温型では弱い反射がわずかに認められるのみである。 Prewitt \& Peacor（1964)によれば parabustamite の有無てついては否定的であ るが, 合成実験の場合には不安定相の出現も考えられる。bustamite：にも $\mathrm{SiO}_{3}$ の鎖状 構造相互のズレによる変態があってもよいと思われるが詳細は今後の問題である。 


\section{参考文献}

Hori, F. : Sci. Pap. Coll. Gen. Ed. Un iv. Tokyo, 12, 117-142 (1962)

Prewitt, D. T. and Peacor, D. R : Am. Mineral., 49, 1527-1542 (1964)

桃井 斉:日本鉱業会誌, 79,836-837 (1963)

Momoi, H。 : Mem. Fac. Sci, Kyushu Univ., Ser. D, Geology, 15, 39-63

(1964)

須崎祐吉：地学研究, 14, 72-87（1963）

\section{〔討 論〕}

森本: Parawollastonite, wollastonite $と$ bustamite, synthetic bustamite の間に構造的にどんな差があるか。

樉井：X線粉末回折線から判断すると, 天然の bustamiteは, 高温合成した bustamite とよく似て抽，熱水王下で合成した bustamite とは異なる。従って後者は天然の bustamite とは異なる chain の配列をもつと考えられるが, それが wollastonite 型か, parawollastonite 型かは分らない。あるいはもっと大きな超格子をもつのか も知れない。

床次：CaSi O の低温形の安定期は wollastonite だけでいわゆる parawollastonite はその無秩序のものと思う。

Mn-Pyroxene の相の数も幾つかの秩序相とその無秩序性を考えれば，比較的少数に整 理されるのではないかと思う。

南部：Rhodonite と pyroxmangite は天然に扑いて同時晶出したと考えられる共生 を示して産出する。それで両者は高温相, 低温相の関係にあるのではなくて化学組成上に 本質的に差異があるのではないか。また両者は合成上, 確実に共存する領域が存在するの か。

楼井：第三紀の鉱脈中ゃ，キースラーガーでは rhodonite と pyroxmangite の共生 が見られる。端成分の $\mathrm{Mn} \mathrm{SiO}_{\mathbf{3}}$ では合成実験で両者の共存領域はないが，混溶する $\mathrm{CaSiO}_{\mathbf{3}}$ があると今回の実験結果では共存镇域がある。天然のものと比較するには，なお $\mathrm{FeSiO}_{\mathbf{3}}$ の入った系の実験をやる必要がある。

Pyroxmangite の構造に水が入る可能性はないか。 森本：Wollastonite の order, disorder は一応 powder で区別でるるので, 第 一段階では, ちがった phase として考えてよいのではないか。 
竹内:Bustamite の structureではCa が orderしているてとになっている。従 って Caの量及びその ordering の様子によって, 構造の相異が当然想像出来る。

又“水”については pectoliteのような例もあるから，水の存在は全然否定的ではな w。

酸化物に及ほす酸素分圧の影響とメスパワー・スペクトル

\author{
"Ef fect of Oxygen Pressure on Oxides and \\ the Mössbauer spectra of ${ }^{\circ} 7 \mathrm{Fe}$
}

新

重 光* (Shigemitsu Shin )

1 気压より低い酸素分圧下での鉱物, 特に鉄酸化物の合成とそれに対応する天然物の比 較から後者の生成環境を知ろうとする試みは古くから精力的な研究がなされているが， 1 気圧より高い酸素分圧下での酸化物の合成に関する研究には第二次世界大戦までは見るへ き成果はなかった。しかしながら最近になって電子材料の開発があちてちで行なわれるよ うになってから，殊に structure-sensitive な遷移金属酸化物の合成に「高酸素王霖 囲気」下での実験の必要性が高まりつつある。このような時期て鉄化合物の研究には欠か すととのでさないメスバワー効果がドイツの物理学者 R。 L M って発見され，鉄酸化物の物性に関する研究は一段と進展した感がある。我々の研究室に 扎ても昨年よりこの点に着目して，100 気圧程度の酸素圧雾囲気下で常圧では得られな いような珍しい化合物を合成し，その生成物の ${ }^{57} \mathrm{Fe}$ のメスバワー・スペクトルを測定し ている。その概要を以下簡単に報告する。

取り报った物質はアルカリ土類金属を含む鉄酸化物 $\mathrm{A} \mathrm{BO}_{\mathbf{3}-\delta}(\mathrm{A}=\mathrm{Ca}, \mathrm{Sr} ; \mathrm{B}=\mathrm{Fe}$ ; $\delta=0 \sim 0.5$ ) で，乙れは酸素䇰囲気と鉄イオンの原子価状態，酸素欠損数，さらには それに結びつく結晶構造等の物性との関連性を検討するのに適した化合物である。出発物 質として, $1 \mathrm{M} \mathrm{Ca}\left(\mathrm{NO}_{3}\right)_{2}, 1 \mathrm{MSr}\left(\mathrm{NO}_{3}\right)_{2}, 1 \mathrm{MFe}\left(\mathrm{NO}_{3}\right)_{3}$ 溶液加 $\left(\mathrm{Ca}_{\mathbf{x}} \mathrm{Sr}_{1-\mathbf{x}}\right)$ $\mathrm{FeO}_{3-\delta}$ を作成し, これら出発物質を $300^{\circ} \mathrm{C}, 100$ 気厈の酸素需囲気中で 1 息夜加熱処

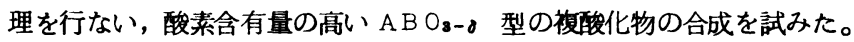

$\left(\mathrm{Ca}_{\mathbf{x}} \mathrm{Sr}_{1-\mathrm{x}}\right)_{\mathrm{FeO}} \mathrm{Fe}_{3-\diamond}$ の端成分である $\mathrm{Ca}_{2} \mathrm{Fe}_{2} \mathrm{O}_{3}$ 扰よび $\mathrm{SrFeO}_{3-\delta}(0 \leq \delta \ll 0.5$ : 格子久宿のない理想的なものは $\left.\mathrm{SrFeO}_{2}\right)$ はそれぞれ斜方晶系の brownmillerite ( $\mathrm{A}_{2}$ $\left.\mathrm{B}_{2} \mathrm{O}_{5}\right)$ および等軸晶系のペロブスカイト $\left(\mathrm{ABO}_{3}\right)$ 型複酸化物であることが知られてい

- 阪大産研 
る。結晶化学的には, $\mathrm{Ca}_{2} \mathrm{Fe}_{2} \mathrm{O}_{5}$ では $\mathrm{Fe}$ の原子価状態はすべて3価で, $\mathrm{Fe}^{8+}$ は酸素 によって半分は 4 配位, 半分は6配位的と囲ま机ている。てれに対し $\mathrm{Sr} \mathrm{Fe} \mathrm{O}_{3-。}$ の理想 格子 $\mathrm{SrFeO}_{\mathbf{z}}$ では $\mathrm{Fe}$ はすべて4 価であり, $\mathrm{Fe}^{4+}$ は 6 個の酸素によって8面体的に

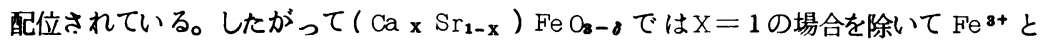
$\mathrm{Fe}^{4+}$ が共存しているてとになり，またその結晶構造は Fe の配位数によって決まるもの と思われる。出発物質はその $\mathrm{X}$ 線回折より， $\mathrm{x}=0$ 〜 0.2ではペロブスカイト型, $\mathrm{x}=$ $0.4 \sim 1.0 て ゙ は b r o w n m i l l e r i t e$ 型であった。との系を前記の条件下で酸素压处理するて とにより, $\mathrm{x}=0 \sim 0.6$ でベロブスカイト型, $\mathrm{x}=0.8 \sim 1.0$ で brownmillerite 型へ と変化した。これは酸化により結晶格子中に酸素が固溶し, $F$ eの配位数が変化したもの と考えられる。X線涀定と併行して試料中の $\mathrm{Fe}^{4+}$ の濃度を決めるために化学分析 （iodometry と permanganate法の併用）を行なったが，その分析值はX線のデータ とよい対応を示した。

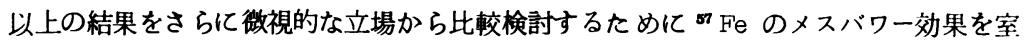
温で観測した。貺定試料は空気中で得られた出発物質 $\mathrm{Ca}_{2} \mathrm{Fe}_{2} \mathrm{O}_{5}-\mathrm{Sr} \mathrm{Fe} \mathrm{O}_{2.77}$ 系扰よび 100 気压の酸素雾囲気下で生成された $\mathrm{Ca}_{2} \mathrm{Fe}_{2} \mathrm{O}_{5}-\mathrm{Sr} \mathrm{FeO}_{\mathbf{2}, 97}$ 系の二系列であり, 線源 としては ${ }^{57} \mathrm{Co}$ ( in $\mathrm{Cu}$ ) を選び，乙れから放射される $14.4 \mathrm{KeV} の r$ 線を使用した。 Doppler velocity の補正は velocity の狭市領域では純鉄の ${ }^{57} \mathrm{Fe}$ のゼーマン分裂 を, 広帢域では $\boldsymbol{\alpha}-\mathrm{Fe}_{2} \mathrm{O}_{3}$ の磁気的超徵細構造（magnetic hfs）を利用して行な った。また isomer shiftは 310 stainless steel の ${ }^{57} \mathrm{Fe}$ の共鳴吸收線の位置を velocity の $0 \mathrm{~mm} / \mathrm{sec}$ とし, ての值と比較したものとして観測された。酸素塞囲気を 変化させても生成物の酸素含有量の変わらなかった $\mathrm{Ca}_{2} \mathrm{Fe}_{2} \mathrm{O}_{5}\left(\mathrm{Fe}^{\mathrm{e}+}\right.$ のみ) は酸素王処

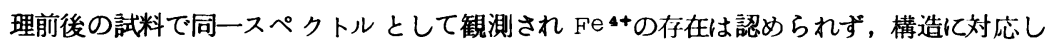
た 2 種の $\mathrm{Fe}$ ( 8 面体場と 4 面体場) の吸収線が現われた。またての試料は室温で磁気的 な規則配列があるので，2種の Fe の各吸收線はそれぞれ6本に分裂した magnetic hfs を示した。てれて対し，酸素王処理により酸素含有量の大きく変化した試料

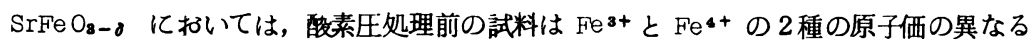
$\mathrm{Fe}$ の吸収線がその isomer shift の差異加認められ, また各吸収線は結晶自体の 僅かな正方歪み（c/a=0.997）による核四重極子分裂が見られ, 試料のX線回折（偽 等軸ペロブスカイト相 ) P化学分折值 $\mathrm{Sr} F \mathrm{Fe}_{2.97}\left(\mathrm{Fe}^{4+} \approx 55 \%\right.$ ) とよい対応性があっ

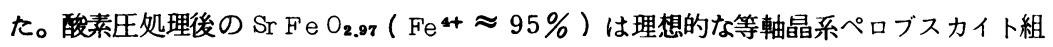

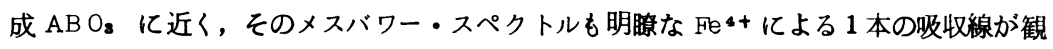
測された。その isomer shift は L. R, Walker et al. (Phys. Rev. Letters, 6, 98 (1961)) による純イオン性の $\mathrm{Fe}^{4+}(3 \mathrm{~d} 4)$ の計算值よりも, ずっと $\mathrm{s}$ 電子密度 の少ない側へずれ，ての結果はこの化合物中の $\mathrm{Fe}^{4+}$ が完全なイオン性でなく酸素の $\mathrm{p}$ 勒 道とかなり重なりのある共有結合性を暗示しているものと考えられる。また $\mathrm{Fe}^{\mathrm{A}}$ の吸収 
線には高スピン型配位子場での $3 \mathrm{~d}$ 基底状態電子配置（ ${ }^{5} \mathrm{D} ）$ から期待されるような Jahn-Teller 効果による分裂は室温で認められなかった。酸素王処理により構造が斜方 晶系 brownmillerite 型 $\mathrm{A}_{2} \mathrm{~B}_{2} \mathrm{O}_{5}$ から等軸晶系ペロブスカイト型 $\mathrm{ABO} \mathrm{O}_{\mathbf{8}}$ 一移行した試 料 ( $\left.\mathrm{Ca}_{0.8} \mathrm{Sr}_{0.8}\right) \mathrm{FeO}_{\mathbf{2 . 8 3}}\left(\mathrm{Fe}^{4+\approx 72 \%}\right.$ ) は, $\mathrm{SrFeO}_{2.97}$ と同じように 1本の明暸な $\mathrm{Fe}^{4+}$ に基く吸収線を示した。しかし線巾については幾分前者の方が広くなって括り $\mathrm{Fe}^{3+}$ の共存を暗示しているものと思われる。

以上の結果をまとめてみると結論的に云えるととは，乙の種の化合物の合成や物性の研 究には酸素分圧を変化させながら実験を行なうことがいかに重要であり，またメスバワー ・スペクトルの測定がいかに多くの知見を与えてくれるものであるかというてとがうから゙ えると思う。さらに鉱物の生成環境を知る上にもとのようなアプローチの什方が何らかの 寄与をするものであると考えられる。

\section{[討 論]}

中平：酸素の久陥という実験的な証拠は何ですか。

新：非常に定性的な答になるが， $300^{\circ} \mathrm{C}$ という比較的低い温度で充分酸素が固体結晶格 子中に入っているという実験事実（化学分析による available oxygenの定量）功, てのような酸化反応は金属イオンよりもむしろ酸素原子の空格子点の拡散がその反応因子 になっているのではないかと考えられる。私自身未だ試料の密度を貺定していないが, 類 似型化合物の $\mathrm{Ba} \mathrm{FeO}$ - ○につては酸素欠損量に関係する $\boldsymbol{\delta}$ の值がその物質の密度との 間に直線的な関係にあるという報告からも，てのような鉄酸化物中の「酸素の久陥」とい う考え方を正当化するものではないだうか。

久米: 酸素の配位数の增加, たとえば brownmillerite構造の酸素が 4 配位加ら固溶量 の増加に伴い6配位に增すととも一つの根拠といえると思う。

定永：r線源を動かすのは Doppler 効果を起とす必要のためか。もしそうだとすればそ の動かし方が非常に遅くてよいのは，スペクトルの現われ方が波長の変化に極めて敏感な ものなのか。

\section{新：そうである。}

中平: メスバワーや結晶場スペクトルが最近, 天然のキ石の $3 \mathrm{~d}$ 元素のものに適用されて いるが，それによってどの程度のととが現在の段階で議論できるのか。

新 : キ石中の 2 つ 8 面体場 $\mathrm{M}_{1}$ と $\mathrm{M}_{2}$ に $3 \mathrm{~d}$ 元素がその生成条件によりどちらの格子 点一好んで入るかはメスバワーや至近赤外〜紫外領域の吸収または反射スペクトルを測定 すれば, 前者に抽は isomer shift として, 後者では結晶場での配位子の強さの差 異による $\mathrm{d}$ - d 遷移エネルギーの差異として原理的には観測できるはずである。しかしな ら前者は現在のとてろ $\mathrm{Fe}$ の核種だけに限られるとと, 後者は固体試料の電子スペクトル を貺定する困難さのため，自らそれらの使用法にも限度があると考えられる。 
森本：キ石中で Fe 核種がどちらの格子点へ好んで入るかは, order-disorder の問題 とからんで，X線とメスバワーとは相補的な役割を果たすものと思う。

小泉：中平氏の新君に対する「メスバワー効果が天然鉱物に果たして有効か。あるいは 特定の元素を含む物質のみにしか応用されないのではないか。」との質問に答えたい。新 君の研究している物質は合成物に限っているので果して天然物の適用に適しているかどう かは今のとてろはっきりはしない。しかし何事も新しい方法を応用する初期段階には必ず このような疑問が生ずることである。また複雑な天然物質の解析にはなるべくいろいろの 方法を併用するのがよいてとはいうまでもないてとである。われわれは新しい実験方法を 導入するのに臆病であってはいけないと思う。

\section{$\mathrm{X}$ 線小角散乱法による粘土鉱物の粒子構造の研究}

A Note on Structure of Clay Minerals by Small-angle X-ray Scattering

\section{渡辺隆 (Takashi Watanabe)}

現在, 無機物のコロイド粒子の研究に広く応用されているX 線小角散乱法を用いて, 粘 土鉱物粒子の微細構造を考えてみたいというのが，ての研究のねらいである。今回は，特 に「X線小角散乱法を用いて粘土粒子の如何なる問題点を追求しょうとするのか。」とい う点にポイントを抽き，現在行なっている実験の二・三を紹介し御批判を得たいと思う。

先ずはじめに，X線小角散乱法から得られる粒子に関する量について述へてもく。

Fankuchen et al.(1946) によれば, 散乱強度式は,

$$
I(h)=K \cdot \sum_{i} M\left(\overline{R_{g} \cdot i}\right) \cdot\left(\overline{R_{g} \cdot i}\right)^{3} \cdot \exp \left(-h^{2} \cdot\left(R_{g} \cdot i\right)^{2} / 3\right)
$$

で表される。但し $\mathrm{h}=2 \cdot \sin \theta / \lambda(2 \theta$ : 散乱角， $\lambda:$ X線の波長 ), Kは定数, $M\left(\bar{R}_{g}\right)$ は, 試料中の $\bar{R}_{g} \sim \bar{R}_{g}+\Delta \bar{R}_{g}$ なる径をもつ粒子の質量分布関数である。 $\bar{R}_{g}$ は, 原点から $\mathrm{k}$ 番目の原子までの距離を， $\mathrm{I}_{\mathrm{k}}$ とし，その散乱因子を $f_{\mathrm{k}}$ とすると，

$$
\left(\bar{R}_{\mathrm{g}}\right)^{2}=\frac{\sum_{\mathrm{K}} \mathrm{f}_{\mathrm{k}} \cdot \mid \mathrm{r}_{\mathrm{k}}^{2}}{\sum_{\mathrm{k}} \mathrm{f}_{\mathrm{k}}}
$$

* 東教大理学部 
で示される “慣性半径”である。さらに, $\overline{\mathrm{R}}_{\mathrm{g}}$ の平均值 $<\overline{\mathrm{R}_{\mathrm{g}}}>$ を求めるととができる。 又, Porod (1951) によれば, 散乱強度式は,

$$
\begin{aligned}
& I(h)=I_{e}(h) \cdot \rho^{2} \cdot \omega(1-\omega) V \cdot \varphi(h) \\
& \varphi(h)=\int_{0}^{\infty} 4 \cdot \pi \cdot r^{2} \cdot H(r) \cdot \frac{\sin (h \cdot r)}{h \cdot r} \cdot d r
\end{aligned}
$$

で示される。こてで, $\mathrm{r}$ は, 試料中の任意の二点間の距離である。 $\mathrm{H}(\mathrm{r})$ は, その粒子系 で任意のベクトル $\vec{r}$ の両端が, ともに, 粒子の内部に存在する確率に関する量である。 それを用いて粒子の大きさに関する量として, 粒子内に含まれる干涉領域の大きさの平均 " $1_{c} "$ を次の式て定義した。

$$
I_{c}=2 \cdot \int_{0}^{\infty} H(r) \cdot d r=\pi \frac{\int_{0}^{\infty} h \cdot I(h) \cdot d h}{\int_{0}^{\infty} h^{2} \cdot I(h) \cdot d h}
$$

又，“粒子の集合状態”を，示すものとして なるものを，

$$
f=\left[\lim _{h \rightarrow \infty} h^{4} \cdot I(h)\right] \cdot \int_{0}^{\infty} h \cdot I(h) \cdot d h /\left(\int_{0}^{\infty} h^{2} I(h) \cdot d h\right)^{2}
$$

で定義している。その值 fは，試料が，球状で均一な大きさの粒子のあつまりならば，1/2 を示し, 粒子の形状が, 球からはなれて, 板状又は, 柱状になるにしたがって, $1 \sim 4$ と いう大きな值をもつようになる。

以上述へたようなく $\overline{\mathrm{R}}_{\mathrm{g}}>$ ， $1_{\mathrm{c}}$, f を求めて, それらを吟味するととにより, 次に のべるような粘土粒子の研究を試みた。

測定に用いた粘土鉱物二種（加水ハロイサイト,アロファン）についての問題点を述へ てみたい。加水ハロイサイト，アロファンは，日本の火山灰土壤の主要粘土鉱物である。 火山咴土襄の粘土鉱物は，その降灰年代の新しいものは，アロファンを主体としているが， 古くなるにつれて, アロファンから生成されたと考えられる加水ハロイサイトやハロイサ イトを混在する割合が大きくなってくると報告されている。とくに加水ハロイサイトは， 電子顕微鏡により"パイプ状”と“栗の款状”及び“タマネギ状”の三つの形が，認めら れている。とれらのちがいは, X線回折では, みとめられないが, 須藤・高橋 (1956)の 指摘したように, “タマネギ状”構造をもつ加水ハロイサイトは, アロファンから加水八 ロイサイトのの変化する過程を, その粒子構造の中に残しているものと考えられる。

以上のような報告からも，アロファン粒子とての“タマネギ状” 粒子との関連を知ると とは, 非常に興味澡いことであろう。

したがって，アロファン粒子，加水ハロイサイト粒子自身の性質を知ることか，第一の 問題となる。 
a) 加水ハロイサイト

加水ハロイサイトは， $110^{\circ} \mathrm{C}$ 加熱により約 $10 \AA \rightarrow 7 \AA$ 亿 $\mathrm{d}_{001}$ は変化するが，との 結晶格子の変化は, 小角散乱現象とどのような影響をもたらすだろうか。

b) アロフォン

アロファンの加熱処理について考えると.この物質は， $300^{\circ} \mathrm{C}$ の加熱によりX線回折 線に変化がみとめられた。この一種の構造变化上小角散乱から得られる粒子の変化との連 関は,どうなるだろうか。

又, 一方アロファンは, 小坂 (1961)の指摘によれば, 鉱物学的性質が $\mathrm{Al}_{\mathbf{2}} \mathrm{O}_{\mathbf{3}} \cdot \mathrm{SiO}_{\mathbf{2}} \cdot \mathrm{H}_{\mathbf{2}} \mathrm{O}$ の共沈澱ゲルと似るという。したがってこのようなものであれば,めのうの乳ばち中での 摩砕などの簡単な, 外的な力で, 粒子が凝集しやすいことが予想される。このような颣集 現象と，小角散乱法から得られた粒子の変化とは，如何なる関連をもつか。

以上のような種々の問題が, 現在ある。これらの問題を, X線小角散乱法を用いて, 先 にのべた $<\overline{\mathrm{R}}_{\mathrm{g}}>, 1_{\mathrm{c}}$, fを求めて検討した。

次に, 測定に用いた試料についてのべる。

a) 加水ハロイサイト

千葉県稲毛産の下末吉ローム首中から, 常法により $2 \mu$ 以下のものを採集した。X線, $\mathrm{D} \cdot \mathrm{T} \cdot \mathrm{A}$ などの分析の結果, 他の鉱物の混入はみとめられなかった。電子顕微鏡の観察よ り"タマネギ状” の球の集りである。

b) アロファン

杤木県鹿沼地方に産する “鹿沼土”より, 得たものである。尚, 化学分析の結果より, $\mathrm{SiO} / \mathrm{Al}_{2} \mathrm{O}_{3}=137$ を得ている。

最後に実験結果についての考察をのべる。

a ) 加水ハロイサイト

測定結果は, $<\overline{\mathrm{R}}_{\mathrm{g}}>=141 \AA ， l_{\mathrm{c}}=334 \AA ， f=1.1$ であった。かなり丸みをおび た粒子の集合体であるととを示している。

加熱物 $\left(110^{\circ} \mathrm{C}, 3 \sim 4 \mathrm{~h}\right)$ につてみると, < $\overline{\mathrm{R}}_{\mathrm{g}}>$, $\mathrm{I}_{\mathrm{o}}$, f の值が, それぞれ, $120 \AA, 267 \AA, 1.3$ に変化している。均一柆子の集合体が, 不均一な粒子の集合体へ変 化したととか⿱, 示されている。したがって, 加水ハロイサイトの粒子は, 結晶格子を単位 として, 構成されているととが, 判明した。

b) アロファン

アロフォンの粒孔についてみると, < $\overline{\mathrm{R}}_{\mathbf{g}}>=39 \AA$ で, しかも, かなり均一であると とが $\mathrm{M}\left(\overline{\mathrm{R}}_{\mathrm{g}}\right)$ の測定より判明した。粒子が $100 \AA$ 以下で均一であるというととは, 沈澱 コロイドの一つの特色である。とれは電子顕微鏡写真から得た粒径と非常によく一致した。 


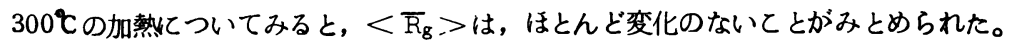
との問題については今検討中である。

つぎに，めのうの乳ばちで摩砕するととは，小角散乱法より得られる粒子に影響を与え るととが確かめられた。まず数グラム風乾した試料を $2 ， 3$ 分間乳ばちで摩砕したものは $<\overline{\mathrm{R}}_{\mathrm{g}}>=145 \AA ， 1_{\mathrm{c}}=411 \AA$ を示し, さらに摩砕したものはそれぞれ $191 \AA ， 472 \AA$ を示した。との結果, 粒子が大きくなっていくことがみとめられた。

又, 以上の結果に加えて, 現在次のような研究を試みた。

粘土鉱物は, X線その他の多〈の研究により, かなりの可能性をもって円盤状粒子であ るととが予想される。今粘土鉱物を円盤状粒子と仮定してX線小角散乱現象を解析してみ た。との仮定に立ってのX線小角散乱の強度式は， hが大きいとてろで，

$$
I(h) \fallingdotseq \frac{2 n^{2}}{h^{2} \cdot R^{2}} \cdot \exp \left(-\frac{h^{2} \cdot H^{2}}{3}\right)
$$

で示される。但し，2Rは円盤の直径，2H は円盤のあつみを示し，

$$
\mathrm{b}=2 \cdot \frac{\sin \theta}{\lambda} \quad(\theta \text { はブラッグ角 })
$$

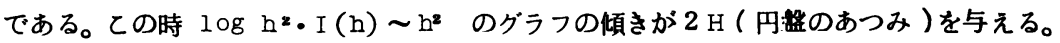
又 $\log h^{2} \cdot I(h) \sim h *$ のグラフで直線部分がみとめられればそれは粒子が円盤状であ るととを示すデータでもある。

この実験で用いた試料は緑泥石二種で, それらは Mg一緑泥石と Al一緑泥石である。 二試料についての溳定結果を, $\log \mathrm{h}^{2} ・ I(h) \sim \mathrm{h}^{2}$ 罒にプロットしてみると両者とも直 線部分がみとめられ，乙れらの二種の粘土鉱物の粒子が円盤状であることが確かめられた。 次に Hauska \& Warrenの方法により求めた $(00 \ell)$ 方向の結晶子の大きさ Lc と, 上で求めた円盤状粒子の厚み $2 \mathrm{H}$ との比較を試みた。その結果 $\mathrm{Mg}$ 一緑泥石については,

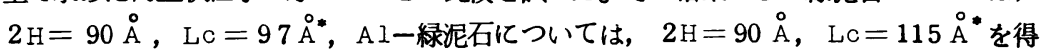
た。その結果, 緑泥石については小角散乱現象を与える粒子の構造単位は結晶格子のひろ がりの大きさ（結晶子）と一致するだろうと考えられて。

以上粘土鉱物の粒子棈造の研究への, 小角散乱法を用いての, 二・三の試みをのべてみ た。

・最近の精度を上げた実吿によればよりよい一致をみた。 参考文献

1. Fankuchen et al, (1946) : Ind. Eng. Chem. 18, 172-175.

2. 小坂丈予 (1961)：粘土科学の進歩第3集) $225-233$. 
3. Porod(1951): Kolloid, Zeit, 133, 16-26.

4. Sudo, T., and H. Takahashi(1956): Proc. 4 th Nat. Conf. Clays and Clay Minerals, 67-79.

\section{[討 論)}

竹内：ハロイサイトの針状と球状という話をしたがその詳しい意味をきさたい。

渡辺：加水八ロイサイトには電子顕微鏡写真加ら針状（パイプ状），タマネギ状 及び栗 の穀状の 3 種の形がみとめられている。球状というのはタマネギ状構造及ひ栗の穀状の両 者を含めている。

湊 : ハロイサイトにメいは 3つの形態(1)棒状（パイプ状 ), (2)渦巻状, (3)栗のいが状 があるように思う。

湾辺：カオリナイトについて

Hauska \& Warrenの方法を用いてのIine profile からの結晶子の評価がうまく いかないがどうした原因によるものか。コメントをいただきたい。

白水：カオリナイトの $00 \boldsymbol{\ell}$ 反射のline profile の問題は僅が d(001)の異なる反射 の混合によると解釈出来ないだろうか。

渡辺：実験に用いたカオリナイトは関白産のものではとんど純粋だと思う。

電顕でパイプ状のものがまじっているのでカオリナィトにハロイナイトがまじっている 可能性はある。

その辺の検討をもう一度行なってみる。しかし（001）の反射にのみ何かのピークが重 なり（002）には重ならないという可能性のものを考えなくてはいけないので，かなりむ つかしいのではないかと思う。

\section{第 1 セッションを司会して \\ 湊秀 雄 ${ }^{*}$ ( Hideo Minato)}

鉱物の生成環境をテーマとして取り上げた今回の鉱物総合研究において, 今回が最後の シンポジウムの機会となった。この機に総合研究の取りまとめとして研究課題そのものの シンポジウムを行なうととが出来たてとは真に意義あることであって，ての計画を立案さ れた世話人各位に厚く御礼を申上げたいと考える。しかし取り上げた問題は鉱物学におい 
てきわめて重要な問題であるととも明らかであって，3ケ年の研究に打いて解明するには 如何にも深遠な問題であるとも云わねばならない。その結果, 今回のシンポジウムにおい： ては結論に到達するととではなく，研究の中間過程の一つの断面を現わし得たものとして， 其処に充分な意味が見出されるものである。

司会者の担当した部門は「鉱物の化学組成と生成環境」扰よ゙鉱物の物理性質と生成 環境」であって，前者の話題として，

1.「マンガンキ石類について」大理学部桃井斉氏よりの報告があり bustamı te 打 よび parawollastonite に拈よび一連の鉱物間に打ける化学組成上の変化につき説明 が行なわれ，乙れて対してマンガン鉱床の研究者より，てれらの鉱物の生成環境に関する 意見が述べられ，種々興味深い問題点が上げられた。なおての問題は比較的高い温度，王 力の下に扔ける鉱物つ生成罢境を取りあつかったものである。

後者の話題としては,

2.「酸化物におよぽす酸素分王の影響とメスバワー・スペクトル」大阪大学産研新重 光氏よりの報告と，

3.「X線小角散乱による粘土鉱物物性の研究」東京教育大学理学部渡辺隆氏よりの報 告とが上げられる。

前者はまず Mössbauer effect の説明より始まり, 数種の酸化物の型式と酸素分王 との関係を明らかにする報告があり，同一金属に対しどのような酸化物が生成するかの問 題に関し，新らしい興味深い試みが取り上げられたものである。後者はX線小角散乱を粘 土鉱物に適用した例であって，すでに維椎の構造の問題解明などに用いられて特徵のある 方法が微細粒子の集合体である粘土類に利用されたものであって，その方法によっては今 後も興味深い利用が期待される分野である。

以上 $3 つ$ 提出された話題の内容は夫々別々のものであって, それらの間に有機的関連 は認められないが各種の異なった方向よりの鉱物の生成環境の解明の手段として閏題を示 すものである。最後に「化学的環境と生成鉱物の化学組成」とも云い得る一例として筆者 の clinoptilolite に打引場合を附記する。試料は鹿児島䝨郡山産の mordenuteを 混在する Ca 型の clinoptilolite であるがてれを NaCl 5\% 水溶液に常温, 常代にて 24 時間処理するととにより，てれを Na 型 clinoptiloliteに変化させた実験である。 陽イオン交換が行なわれたのであるがてれを $\mathrm{K}, \mathrm{Na}, \mathrm{Ca}$ の戝に記入すると第1罒に扔 て示すような組成を有するものである（ $\mathrm{K}_{1}$ ：原試料（Ca 型）， $\mathrm{K}_{2} ： \mathrm{NaCl}$ 処理物 ( $\mathrm{Na}$ 型 ， $\mathrm{C}_{1}$ ：Ca型一石見太田産， $\mathrm{C}_{4} ： \mathrm{~K}$ 型一板谷産， $\mathrm{C}_{5} ： \mathrm{Na}$ 型一三ツ井産, $\mathrm{C}_{3}$ は父 島産 heulandite, $\mathrm{K}_{3}$ は $\mathrm{K}_{2}$ を再び $\mathrm{CaCl}_{2}$ 溶液中（ $5 \%$, 室温, 常生, 24 時間）に で処理して Ca 型に変化させた試料) 各試料を $400^{\circ} \mathrm{C}, 4$ 時間加熱した結果は $\mathrm{Ca}$ 型 と $\mathrm{Na}$ 型およびK 型の間にもいて夫々の結晶の破壊に差異が認められる。第 2 図にその状態 を示すが，人工的に変化させた $\mathrm{Na}$ 型試料は天然の $\mathrm{Na}$ 型試料と熱的性質にもいて類似性 
を示す。この一連の実験は低温, 低左下にもける鉱物の生成環境において, その化学的環 境のおよぼす影響と鉱物の化学成分と物性との関係などの問題を検討するにあたり, 一つ の話題となるであろう。 